\title{
PLACEMENT AND DELEGATION AND ITS EFFECT ON EMPLOYEE WORK DISCIPLINE AT SMA NEGERI 1 BELITANG MADANG RAYA OGAN KOMERING ULU TIMUR
}

\author{
Yansahrita \\ STIE Trisna Negara, South Sumatra \\ Email : yansahrita82@gmail.com
}

\begin{abstract}
Delegation and placement are very important in the effort to implement good teaching and learning activities. This study aims to analyze partially and jointly the effect of placement, delegation of authority on employee work discipline and to analyze the most dominant variables in influencing employee work discipline at SMA NEGERI 1 Belitang Madang Raya Ogan Komering Ulu Timur, Results of regression analysis and correlation between placements. Work towards employee work discipline shows the regression model $\mathrm{Y}=5.443+1.006 \mathrm{X} 1+\mathrm{e}$ with a correlation coefficient of 0.880 . The results of regression analysis and correlation between delegation of authority to employee work discipline show the regression model $\mathrm{Y}=17.242+0.654 \mathrm{X}$; $+\mathrm{e}$ with a correlation coefficient of 0.826 . The results of multiple regression analysis and the correlation between job placement and delegation of authority jointly to job discipline show the regression model $\mathrm{Y}=5.309+0.683 \mathrm{X} /+0.292 \mathrm{X} 2+\mathrm{e}$ with a correlation coefficient of 0.911 at the $95 \%$ confidence level, it is found that the assignment and delegation of authority are simultaneously can predict employee work discipline. Work placement and delegation of authority simultaneously have a positive influence which is quite close with work discipline of $81.5 \%$ and has a significant effect. This research was conducted on 25 respondents with the analytical method used is path analysis using SPSS software.
\end{abstract}

Keywords: Delegation of Authority, Placement, Work Discipline

\section{Introduction}

Employees as state officials have a very important role in the harmony of the activities of the organization where they work. In action it must always be oriented towards organizational goals and encourage the agency to achieve the goal is to be able to improve performance, optimize services to the community, which in turn can support the achievement of national development goals. To achieve these objectives, one of them is the placement factor which is an important factor for agencies in achieving predetermined goals. Therefore, leaders must make the right placement so that employees can achieve optimal performance in the form of work productivity. By looking at the tendency of inaccurate placement of the leadership so that employee discipline is lacking, this condition should not be allowed to continue because it can affect the level of employee work productivity.

Accuracy in placing employees in the right position is one of the important factors in an effort to arouse employee morale and enthusiasm. Agencies that do not carry out employee placement 
properly and correctly can have several consequences such as decreased morale and enthusiasm for work, work performance which will result in lowering the productivity of the agency itself. With improper placement, a person's performance will not match management's expectations and organizational demands, thus they display low work productivity which can result in boredom and boredom.

Employee placement is expected to provide an adequate contribution to the organization as well as an effort to develop the competence of human resources in the organization. The suitability of the placement of employees with their duties greatly affects job satisfaction and performance of the employees concerned. In this relationship an organization will succeed or fail is largely determined by the leader. This can be seen how a leader behaves and acts. How to behave and act can be seen by doing a job. A noble expression says that the leader is responsible for the failure to carry out a job. This is an expression that places a leader in a government agency in particular, in the most important position.

\section{Literatue Review \\ Definition of Work Placement}

Implementing the right job placement of employees in the right position is not only the dream of the agency, but also the desire of the employees concerned so that they can find out the scope of work assigned to them. According to Bedjo Siswanto (Malayu, 2011; P.180), employee placement is "As an experimental step which is a definitive step consisting of: what according to estimates the supervisor in question can be done by new workers with what is requested by the worker (worker conditions). ), what burdens it (fatigue, working conditions and so on), and what workers offer (in the form of intrinsic interest, promotions, payments or rewards)".

It can be concluded that,

- Employee placement is the process of assigning tasks and jobs with the authority and responsibility of the portion and composition applied.

- Employee placement is carried out so that the employee has a position, where he / she works for the job that is best and most suitable for him and the individual needs of the employee.

Employee placement is an ongoing process. employees are not simply assigned to a job and then forgotten about. Employees want even greater duties and responsibilities in the form of promotions. So in this case the definition of employee placement must be interpreted dynamically, in the sense that in addition to short-term interests, it is necessary to think about the long term. However, the current theory of human resource management emphasizes that placement does not only apply to old employees who have experienced transfers and transfers. This means that the concept of employee placement includes promotion, transfer and demotion.

According to Edwin B. Flippo (2010; p. 108) the definition of promotion is "Promotion means a move from one position to another that has a higher status and responsibility". Transfer of duties has two meanings, namely:

a. The assignment of a person to a new task with responsibilities, a hierarchy of positions and an income that are relatively the same as the old status.

b. A worker doing the same or similar work, his income does not change and the responsibilities are relatively the same. 
c. Demotion is the movement of employees who have decreased in rank or position and income as responsibilities are getting smaller.

In placing employees, it is necessary to consider the factors that may greatly influence the continuity of the agency. factors that must be considered in the placement of employees are:

a. Academic Achievement Factors.

Employees who have high academic achievements must be placed in tasks and jobs that are estimated to be capable of carrying them. Even though these tasks and jobs are considered heavy, they require great authority and responsibility. On the other hand, employees who have an academic background that is just below the standard are placed in light tasks and jobs, namely tasks and jobs that only have relatively low authority and responsibility.

b. Experience factor.

Employees who have work experience tend to have relatively high skills and job skills. On the other hand, if you don't have work experience, you tend not to have the expertise and skills.

c. Physical and Mental Health Factors

Physical and mental health need to be considered in assigning employees because without consideration, things that would harm the agency are not impossible. The physical condition of the employee concerned to consider the place where the employee is to be assigned the job and the job that is suitable for him based on his physical condition. employees whose physical and mental conditions are low or weak should be placed in sections that do not really need strong employees, and vice versa.

d. Marital status factor

Marital status really needs to be considered in the placement of the employee concerned. Female employees who have husbands need to be considered especially if they already have children. On the other hand, the employee concerned is placed in a job that is less risky, it is sufficient to be given a job that is in balance with his physical condition.

\section{Definition of Delegation of Authority}

Delegation of authority by superiors to subordinates is necessary in order to achieve the efficiency of the functions in the organization, because no one superior can personally complete or fully means that authority is obtained by someone because of special expertise as a result of experience, popularity, ability to make decisions exact. From the above understanding, it can be concluded that the duties and authorities can be delegated. whether responsibility can be delegated. the authority of the top-level leadership / principal can place the responsibility on the line manager (deputy, head of the program, mentor teachers and / or other staff) to achieve certain goals, only may be analyzed, the top-level leader / principal remains responsible for the overall results.

Delegation of authority is the most fundamental process in the organization, because the leadership will not be able to do everything and make every decision. Superiors or school principals must give others the authority to make decisions and carry out several functions. Superiors or school principals who are reluctant to delegate duties and authority are often caused by themselves who do not trust others. 


\section{Authority due to law (Juridis Authority)}

This means that the authority is obtained by a person because of the law or statute. The formal relationship between superiors and subordinates is only based on the authority of the leader to coordinate and lead his subordinates on the basis of his authority. This does not mean that leaders can take arbitrary actions against their subordinates because there are limits of authority, including the following:

a. Physical (physical) abilities

This means that leaders cannot command a task to their subordinates beyond human ability.

b. Be natural

This means that the leadership cannot assign subordinates to oppose the nature of nature.

c. Technology

This means that the leadership's authority is limited by technology. For example, leaders cannot order their subordinates to carry out unattainable tasks.

d. Economic restrictions

This means that the authority is limited by economic conditions. For example, the leader cannot rule or impose his will on market prices and competition.

e. Partnership agreement

This means the leadership authority is also limited by colleagues, for example by the board of commissioners.

f. Institution

This means that the leadership's authority is limited by the articles of association and bylaws, policies and procedures of the institution.

g. Laws

This means that the leadership's authority is limited by law, religion, tradition and human rights.

Leaders can only delegate authority, while responsibilities cannot be delegated to subordinates. The leader must still be responsible for the authority he delegates, although every delegate who receives the authority must be accountable to the delegator, the last person in charge remains in the hands of the delegator.

\section{Definition of Work Discipline}

The meaning of work discipline is discussed in two parts. First, a discussion of the definition of discipline, in the second part, we will discuss the meaning of work. Then the two terms are combined into one meaning, namely work discipline.

Based on the explanation above, discipline can be interpreted in this study as a situation in which people who are members of an organization train themselves to behave in accordance with a regulated pattern of behavior so that an orderly and orderly state occurs.

According to The-Liang Gie, in his book Efficiency of Work for State Development, what is meant by work is: "The entire implementation of physical, spiritual activities carried out by humans to achieve certain goals, or contain a specific purpose related to their survival". 1981: 73).

In accordance with the limits of discipline and work limitations, what is meant by work discipline in this research is an orderly and orderly condition where the behavior of people who are members of a cooperative effort trains the mind and character to carry out orderly and orderly physical 
and spiritual activities in accordance with defined patterns of behavior. Work discipline is the sixth operative function of human resource management and has the most important role, because the better the work discipline of employees, the higher work performance they can achieve. Without good work discipline, it is difficult for institutional organizations to achieve optimal results.

Work discipline requires the ability to live up to the rules, law and order so that they will consciously implement and obey them. Good work discipline reflects a person's sense of responsibility for the tasks assigned to him. This encourages passion and morale that supports the realization of the goals of agencies, employees and society.

Creating good order in agencies is very necessary, which is through regulations to provide guidance and counseling to employees. Because with good employee discipline, the morale of work efficiency and work effectiveness of employees will increase. Work discipline is enforced by imposing disciplinary sanctions / penalties for each disciplinary violator. Work discipline violation is every word and action of an employee that violates the provisions or rules of employee work discipline that is carried out inside or outside working hours, while work discipline punishment is a punishment imposed on those who violate the employee work discipline rules.

The levels of the types of employee work discipline penalties can be divided into:

1) Light disciplinary punishment consists of an oral warning, a written warning and a written statement of dissatisfaction.

2) Moderate disciplinary penalties include postponing periodic raises, decreasing salary equal to one periodic increase and delaying promotion.

3) Severe disciplinary punishments include demotion, to a lesser degree, release from office, termination of employment unhappily.

In disciplinary action it is necessary to pay attention to several guidelines (Heidrachman Ranupandojo and Suad Husnan, 1985: 228), among others :

1) Discipline should be done privately.

2) Discipline must be constructive.

3) Discipline must be carried out by superiors or direct leaders immediately.

4) Justice should not provide discipline on the time of subordinates is currently absent.

5) Leaders should not give discipline to subordinates currently absent.

\section{RESEARCH METHODS}

\section{Data source}

Sources of data used in this study are:

1) Primary data Namely data obtained from within the company by conducting direct research.

2) Secondary Data That is data obtained from outside the research which comes from college books that have something to do with research.

\section{Data Collection and Processing}

The collection and processing of data used in this study are:

1) Library Research, namely collecting data by studying various kinds of literature, scientific books related to research. 
2) Field Research (Field Research) That is research that comes directly to the object of research to see and research directly. This research was conducted by:

- Observation, namely data collection by direct observation at the location.

- Questionnaires, collecting data by providing a list of questions to leaders or employees.

- Interview, how to obtain data by holding a dialogue or direct question and answer with the relevant company.

- Documentation, namely data obtained by viewing documents or records related to research

\section{ANALYSIS \& DISCUSSION}

The data used are primary data in the form of questionnaires distributed to employees of SMA Negeri 1 Belitang Madang Raya Ogan Komering Ulu Timur. There are two variables studied by the researcher, namely the first variable is the independent variable which consists of the assignment and delegation of authority variables, while the second variable is the dependent variable, namely the employee work discipline variable.

\section{Data Analysis Techniques}

1) Likert scale

R. S. Likert developed a scaling procedure in which the scale represents a bipolar countinum, on the left end with low numbers representing negative answers, while the right hand corner with large / high numbers represents positive answers. The Likert format is designed to allow employees to answer at various levels on each item that describes the variables under study.

2) Validity Analysis

Validity represents the level used as supporting evidence for conclusions drawn from the value derived from the level at which the scale measures something that must be measured. A data is said to be valid if the value of the corrected item is greater than the value of $r$ table with $\mathrm{df}=\mathrm{n} \sim$ 2 or the validity of the instrument for the three variables is assessed by calculating the data using the Pearson Product Moment formula in the SPSS computer program. The statement / question items are declared valid if the Pearson Product Moment > r Tabs; marked with $(*)$ and $(* *)$. The critical number for the correlation table (Table $r$ ) is 0.361 . This figure is obtained from the $r$ product moment table at a significance level of $5 \%(<1=0.05)$ and $\mathrm{N}=25$ (according to the number of respondents). Thus, if there is a correlation coefficient of question / statement items below 0.361 , it is declared invalid.

3) Reliability Analysis

Reliability is a value that shows the consistency of a measuring device in measuring the same symptoms. Reliability is used as how far the measurement is free from error variants in estimating the reliability of the variables under study. Researchers use the Cronbach Alpha method using SPSS computer program tools. An instrument variable is said to be reliable if the CrOnbach's Alpha value is> 0.6. The placement reliability test obtained the Cronbach Alpha value of 0.692, the reliability test of delegation of authority obtained the Cronbach Alpha value of 0.765 while the employee work discipline reliability test was obtained the Cronbach Alpha value of 0.720 
4) Correlation and Regression Analysis

Using associative testing that aims to determine the relationship between two variables, sena regression analysis to find equations. To measure the effect of the relationship between variables, the quantity to be analyzed is correlation (r). The coefficients ranged between -1 and 1 , the closer to one absolute value the correlation coefficient, the stronger the influence between these variables, while the smaller (close to zero) the absolute value of the correlation coefficient, the weaker the influence between these variables. While regression testing is used to see the effect of the variables studied using multiple linear regression and simple linear regression.

The results of the regression analysis and the correlation between job placement and employee work discipline show the regression model $\mathrm{Y}=5.443+1.006 \mathrm{X} 1+\mathrm{e}$ with a correlation coefficient of 0.880 . The results of regression analysis and correlation between delegation of authority to employee work discipline show the regression model $\mathrm{Y}=17.242+0.654 \mathrm{X} ;+\mathrm{e}$ with a correlation coefficient of 0.826 . The results of multiple regression analysis and the correlation between job placement and delegation of authority jointly with job discipline show the regression model $\mathrm{Y}=5.309+0.683 \mathrm{X} /+$ $0.292 \mathrm{X} 2+\mathrm{e}$ with a correlation coefficient of 0.911 at the $95 \%$ confidence level, it is found that the placement and delegation of authority can simultaneously predict employee work discipline. Work placement and delegation of authority simultaneously have a positive influence which is quite close with work discipline of $81.5 \%$ and has a significant effect. This research was conducted on 25 respondents with the analytical method used is path analysis using SPSS software.

\section{CONCLUSION}

From the results and discussion, the following conclusions can be drawn:

1) Jointly Placement (X1) and Delegation of authority (X2) together on employee work discipline (Y) SMA Negeri 1 Belitang Madang Raya, but the placement variable has a more dominant influence compared to the delegation of authority, namely $\mathrm{Y}=5.309+0.683 \mathrm{X} ;+0.292 / \mathrm{Y} ;+\mathrm{e}$ with a correlation coefficient of 0.911 at the $95 \%$ level of confidence, it is found that the simultaneous assignment and delegation of authority can predict employee work discipline.

2) Test all the variables studied were declared valid and reliable, namely the placement reliability test obtained a Cronbach Alpha value of 0.692, a reliability test of delegation of authority obtained a Cronbach Alpha value of 0.765 and a work discipline reliability test obtained a Cronbach Alpha value of 0.720 with a standard Cronbach Alpha reliability value. 30.6

With the results above, it is hoped that the employees of SMA NEGERI 1 Belitang Madang Raya, Ogan Komering Ulu Timur, can improve their work discipline optimally, especially in understanding the stages of work that must be carried out, carrying out tasks according to technical requirements and being able to improve their creativity. For the leadership of SMA NEGERI 1 Belitang Madang Raya, Ogan Komering Ulu Timur, it is suggested that they be able to pay attention that leaders must be able to make the right placement to employees and also delegate authority to the right one to be trusted. 


\section{REFERENCE}

Dharma, Agus. (1985). Perilaku dalam Organisasi. Jakarta: Erlangga.

Flippo, B. Edwin. (1984). Manajemen Personalia (terjemahan). Jakarta: Erlangga.

Handoko, Handoko, Hani T, 1985. Manajemen, BPFE, Yogyakarta.

Hasibuan, Malayu S.P. (2001). Manajemen Dasar, Pengertian, dan Masalah. Jakarta: Bumi Aksara.

Nitisemito, Alex S. (1996). Manajemen Personalia. Jakarta: Ghalia Indonesia.

Robbines, Steven P. 2003. Perilaku Organisasi, Edisi Bahasa Indonesia Jilid 2. PT. Indek Kelompok Gramedia, Jakarta.

Siagian, Sondang P. 1995. Teori Motivasi dan Aplikasinya. Jakarta: VT. Rineka Cipta.

Simamora, B. 2002. Panduan Riser Perilaku Konsumen, PT. Gramedia Pustaka Utama, Jakarta.

Stephen P. 1998. Perilaku Organisasi, Konsep Kontroversi, Aplikasi, Edisi Bahasa Indonesia Jilid 1. Jakarta: PT. Prenhalids.

Stoner, James AF., R. Edward Freeman, Daniel R G R. Gilbert Jr., Manajemen, 1996. Diterjemahkan Sindiro. PT. Prenhalido, Jakarta.

Tomatala, Yakob. (1997). Pendelegasian. Malang: Gandum Mas.

T. Hani. (1999). Manajemen. Jogjakarta: BPFE. Handoko,

T. Hani. (2000). Manajemen Personalia dan Sumber Daya Manusia. Jogjakarta: BPFE.

Umar Husein, 2000. Riser Sumber Daya Manusia. Jakarta; PT. Gramedia Pustaka Utarna, Jakarta.

Umar Husein, 2003. Metode Riser Bisnis. PT. Gramedia Pustaka Utama, Jakarta. 